\title{
TOXIC AND TERATOGENIC EFFECTS OF COPPER SULPHATE ON THE DEVELOPING EMBRYOS AND LARVAE OF SILVER CARP, HYPOPHTHALMICHTHYS MOLITRIX VAL. AT TWO TEMPERATURES
}

\author{
Nabil K. El-Fiky \\ Zoology Department, Faculty of Science, Tanta University
}

Key words : Toxicity, teratogenicity, copper, sulphate, embryonic development, Silver carp, Hypophthalmichthys, temperaturer

\begin{abstract}
ABSTARCT
Q ualitative, quantitative, morphological, histopathological and scanning electron microscopy studies were combined to evaluate the effect of three different concentrations of copper sulphate $\left(\mathrm{CuSO}_{4}\right)(0.15,0.2$ and $0.3 \mathrm{mg} / \mathrm{l})$ on the embryonic development and newly hatched larvae of silver carp, Hypophthalmichthys molitrix (Valenciennes, 1844).) The general development was described briefly. The tail bud stage becomes visible after 32 hours of fertilization, while pharyngula stage becomes visible after about 40 hours. Severe defects during embryonic development arise in the experimental groups. The rate of embryonic development was shorter at higher temperature in both control and metal exposed groups. Hatching started almost 15 hours earlier at $26^{\circ} \mathrm{C}$ than at $20^{\circ} \mathrm{C}$. At both temperatures, as the concentration of copper in water increased the percentage of deformed larvae increased, comparing to that of the control. At both temperatures, all normal larvae from copper sulphate exposure began dying gradually from the beginning of rearing. The survival rate of the deformed larvae was considerably lower. Copper sulphate that caused growth inhibition might have been related to under-developed swimbladder which impaired fish activity and feeding. The neurotoxic effect of copper sulphate on silver carp involves a retardation of neurological development of the superficially located neuromasts on the head. The neuromasts which are segmentally arranged exhibits bi-directional polarity. Copper sulphate also caused inhibition of skeletal ossification which might have resulted from disturbance of ionic regulation. The malformations of the deformed larvae (vertebral curvature \& locomotion) caused
\end{abstract}


impairment of swimming and feeding. Copper sulphate becomes a strong toxicant in excessive concentrations (from $0.15 \mathrm{mg} / \mathrm{l}$ ). Copper sulphate less than $0.1 \mathrm{mg} / \mathrm{l}$ is considered to be suitable for the control of algae (algicide), in lakes, reservoirs and fish cultures (Stominska and Jezierska, 2000). We could also safely use this substance for killing bacteria and parasites in fish culture (Roberts and Beitinger, 1974).

\section{INTRODUCTION}

With increased industrialization, contamination of the environment has reached an alarming proportion. Industrial effluents containing toxic substances including heavy metals escape daily into the aquatic environment.. Consequently, the fauna inhabiting such waters is exposed to the toxic effects of these metals. Heavy metals in water are particularly dangerous for fish and may considerably reduce fish density, or even cause extinction of the entire fish population in polluted reservoirs. Metal concentrations which do not affect adult fish may be toxic to larvae and embryonic stages. The early life stages represent a sensitive part of the life cycle of fish. Environmental conditions durimg embryonic development may affect not only embryos, but also the hatched larvae, and their further development.

The toxicity of heavy metal compounds, specially of that copper salts to fish is interesting not only because of the occurrance of copper in trade wastes, but also because copper sulphate $\left(\mathrm{CuSO}_{4}\right)$ is used on a large scale as an algicide in lakes and reservoirs. It is considered to be very suitable for the control of algae because it forms heavy insoluble compounds with proteins and other constituents of algal cells which sink to the bottom and are then removed from the main mass of water ( Jezierska and Stominska,1997; Stominska, 1998 ;Stominska and Jezierska, 2000). Roberts and Shephered (1974) and Schnick (1974) reported the use of copper sulphate for killing external bacteria and parasites in salmon cultures.

A number of investigators (Wong et al., 1977; Weiner and Giespy, 1978; Vidal, 1978; Gutierrez et al., 1978; Richards and Beitinger, 1995; Jezierska et al., 1995; Mis and Bigaj, 1997; Bieniarz et al., 1997; Sarnowska et al., 1997 and Jezierska, 1998) have studied 
Toxic and teratogenic effects of copper sulphate on the

$\left(\mathrm{CuSO}_{4}\right)$ toxicity and reported rather varied results. Many pathological changes have been reported due to the presence of copper ions (or coumpounds) in water. Williams and Wootten (1981) studied the effects of $\mathrm{CuSO}_{4}$ and formalin on the enzymatic activity in the plasma and its histopathological effects on the liver of rainbow trout.

Among the natural factors affecting development, temperature is one of the most important, as its effect on the embryonic development rate is well known. For each species, there is a thermal range within which development is possible, and the optimum temperature may be determined. The optimum one for the common carp is about $20^{\circ} \mathrm{C}$ (Tatarko, 1965 and Alabaster and Lloyed, 1980). Many data by various authors show the effect of temperature on metal-induced fish mortality (Lloyd, 1960; Amend et al., 1969; Gupta and Rajbanshi, 1988; Richards and Beitinger, 1995), metal accumulation in fish body (Macleod and Pessah, 1973; Wang and Eckmann, 1994; Yediler and Jacobs, 1995), and their toxicity (Alabaster and Lleyod 1980). These data refer to adult fish and fingerlings only. However, other data (Tatarko, 1965; Wang and Eckmann, 1994 and Lugowska and Jezierska, 2000) show the effect of temperature on metal-treated eggs and larvae .

A close correlation seems to exist between the ontogeny of the sense organs and the change of behaviour of the common carp. The free neuromasts are present at hatching and become functional, as a mechanoreceptor, when they are present in well developed cupulae, at this time the eyes are still non-functional. After 4 days of hatching the eye become functional, cones and rods of the retina increase the visual sensitivity and the larvae start swimming and feeding and the neuromasts increase in number (El-Fiky, 1993 and El-Fiky and Bahaa, 1994). Exposure to pollutants can alter the normal behaviour of fish larvae and consequently may affect its ability to react to the environment. Lashein (1999), revealed the retardation of sensory organs of grass carp larvae, in cadmium and lead exposed groups.

Provocative questions could be asked, concerning $\mathrm{CuSO}_{4}$ teratogenicity: First, what is the suitable concentration of copper sulphate which can be used safely in fish culture as algicide in lakes and reservoirs? Second, what is the effect of higher concentrations of copper sulphate at different temperatures (e.g. $20^{\circ} \mathrm{C}$ and $26^{\circ} \mathrm{C}$ ) on 
early embryonic and larval stages of silver carp (Hypophthalmichthys molitrix Val.)? The aim of the present study is to answer these questions.

\section{MATERIAL AND METHODS}

Fertilized eggs and one day old larvae of silver carp (Hypophthalmichthys molitrix, Valencienues, 1844)). were obtained commercially from a fish culture station (Fawa, Kafr El-Sheich governorate). The eggs were fertilized in about two hours after stripping, using the "dry" method (Lugowska and Jezierska, 2000) mixing them with sperm in a bowl. Spermatozoa were activated with water of $20^{\circ} \mathrm{C}$. The gametes were carefully mixed for five minutes. The eggs were rinsed with water of $20^{\circ} \mathrm{C}$ to remove excessive milt. The fertilized eggs, embryos and larvae were kept in the laboratory, in aquaria containing dechlorinated tap water, and maintained under a good aeriation condition.

Staging series is a tool that provides accuracy in fish developmental studies. This is because different embryos, even those found together within a single clutch, develop at slightly different rates. One can determine the approximate developmental stage of a living embryo by examining it with a dissecting microscope, generally with transmitted (not epi- or incident) illumination and with a high magnification. During segmentation period, the tail elongates and if the embryo is left within its chorion, the tail eventually curves over the trunk and head in such a way to obscure the view. When this happens, one must remove the embryo from its chorion, manually with a forceps to stage it. It is always better to stage embryos while they are alive rather than after killing and fixation. Nevertheless, if preservation is good enough, one can easily reliably stage fixed and whole mounted embryos.

Concentrations of heavy metals in polluted reservoirs are never constant. They depend on the type and degree of pollution, Physiochemical conditions, temperatures and time of exposure. In natural water, soluble metals are quickly bound into insoluble compounds, or are sorbed by mineral and organic fractions of bottom sediment. Metals also precipitate from the solution in laboratory conditions (Stominska and Jezierska 2000). To avoid such problems, the experiments were carried out during a short time (about 10 days) and at different concentrations. 
Toxic and teratogenic effects of copper sulphate on the

developing embryos and larvae of silver carp

\section{Experimental set-up and copper sulphate assay}

Toxicity effect of copper bioassays on silver carp at $20^{\circ} \mathrm{C}$ and $26^{\circ} \mathrm{C}$ was employed in this study (Fig. 1). Under this system, copper sulphate levels were in the ranges between $0.05-0.5 \mathrm{mg} / \mathrm{l}$. The number of larvae was 25 for each concentration. The experiment was run at two different temperatures. The exposure period was chosen to last for 48 hours, because the exposure period of fish to high levels of CusO 4 in ditches is similarly short (Lugowska and Jezierska, 2000). After exposure, the larvae were placed in uncontaminated fresh water and left for an additional 48hs. Deaths occurring during this 48 hours period were considered to be due to copper sulphate exposure.

Control embryos were incubated in uncontaminated dechlorinated water. These embryos were spread with plastic spoom in the sieves, 100-200 eggs in each. The stages of embryonic development were distinguished according to Witeska et al. (1995), cleavage (1.2-1.5 hours), blastula (2.2-2.5 hours), body segmentation (22-23.5 hours) eye pigmentation (40.5-42 hours), start of hatching (79.5-82 hours) and end of hatching (88-91.5 hours).

In experimental groups, copper sulphate ( $\left.\mathrm{CusO}_{4}\right)$ solutions were added to obtain the final concentration of $0.15 \mathrm{mg} / \mathrm{l}$ of copper (series I ), $0.2 \mathrm{mg} / \mathrm{l}$ (series II) and $0.3 \mathrm{mg} / \mathrm{l}$ (series III). Each group of silver carp was incubated in 3 replicates (sieves). To evaluate the effect of copper at $20^{\circ} \mathrm{C}$ and $26^{\circ} \mathrm{C}$ during the embryonic development . All sieves containing embryos and larvae were rinsed in water of $20^{\circ} \mathrm{C}$ (control and series I-III) as a general group A and of $26^{\circ} \mathrm{C}$ (control and series I-III) as a general group B. The temperature $\left(20^{\circ} \mathrm{C}\right.$ and $26^{\circ} \mathrm{C}$ ) were maintained with $0.5^{\circ} \mathrm{C}$ accuracy. The effect of copper sulphate on hatching was shown in (Fig. 2).

Dead embryos were removed from the sieves to prevent pathogens development. The dead larvae were counted and removed daily. The embryos, which were transferred to Petri dishes with the same solution as that in the incubation aquaria, were observed using stereo microscope. The observed larvae were divided into 3 groups : 1- Normal (live, motile, without visible anomalies).

2- Deformed (live, moving erroneously, showing body malformation).

3-Dead (immobile, opaque and whitish). 
The percentages of these groups in total number of hatched larvae were calculated. (Fig. 3). Twenty living larvae from each group (norml, deformed) at $20^{\circ} \mathrm{C}$ and $26^{\circ} \mathrm{C}$ were transferred to new sieves suspended in aquaria and reared at the same temperature of the experiment though in $\mathrm{CuSO}_{4}$-free well aeriated water, to study the possibility of recovering from some lesser malformations, such as vertebral curvature, which allow the fish to survive. The fish were fed with Artemia nauplii after the period of internal feeding.

\section{Histological investigations:}

For histological investigations and whole mount preparations, embryos and larvae from different groups were fixed in $10 \%$ formalin for 24 hours, washed in tap water, then dehydrated, cleared and impregnated in three changes of molten paraffin wax at $58^{\circ} \mathrm{C}$ and were then embedded in paraffin. Transverse serial sections were cut at $7 \mathrm{um}$. Sections were stained with haematoxylin and eosin stain according to Bucke (1972) method.

\section{Whole mount preparations:}

Whole skeleton preparations of specimens were accomplished by methods of Dingerkus and Uhler (1977) \& Park and Kim (1984). Larval samples wene fixed in neutral formalin, cleared and differentially stained with alcian blue and alizarine red.

\section{SEM preparations :}

For scanning electron microscopy, the dechorionated embryos and larvae were fixed overnight in $2.5 \%$ glutaraldehyde solution in phosphate cacodylate buffer at $\mathrm{pH} 7.4$, postfixed in $1 \%$ osmium tetroxide, dehydrated in a graded series of ethanol, dried in a critical point dryer, mounted on stubs, and sputter coated with gold palladium in a polaron E5100 unit. Specimens were viewed with JEDL JSM. 5200 according to Kawase (1996) method. 
Toxic and teratogenic effects of copper sulphate on the 233 developing embryos and larvae of silver carp

\section{RESULTS}

\section{Embryogenesis (Fig. 6):}

By observing the normal embryonic development of silver carp (control specimens), a variety of morphogenetic changes could be noticed, after the blastula stage (Fig. 6, b), the somites develop (Fig. 6 , c), the rudiments of the primary organs became visible, also the tail bud became more prominent (Fig. 6, d). We might have called the last stage the 'tail bud stage' (40- hours after fertilization), because at this stage, the tail bud appears clearly at the caudal end. 79 hours after fertilization, the embryo elongates and the caudal end of the lengthening axis shows the tail "Pharyngula period" (Fig. 6.e). Ballard (1981), noted that all vertebrates pass through a common developmental stage, with the distinguishing characteristics of different vertebrate classes becoming apparent only at later stages. This common, or phylotypic stage has since been termed the pharyngula, due to the prominent series of arches surrounding the pharynx. In addition to these pharyngeal arches, the embryos of fish and other vertebrates also possess a distinct brain and sensory organs, a segmental series of somites extending along much of the length of the body, as well as the general chordate characters of a notochord and a dorsal nerve tube. Pigmentation is prominent in the eye (Fig. 6.e), but it is still light enough, to allow the detection of the unpigmented cell nuclei in the retinal epithelium. Melanophores also appear laterally on the trunk and tail, some of them are lodged in the region of the horizontal myoseptum, where the lateral stripe will form. During the hatching period (Fig. 6. F), the embryo continues to grow. Morphogenesis of many of the organ rudiments is now rather complete and the rate of growth slows down considerably, with some notable exceptions including the gut and its associated organs. However, these endodermal structures are difficult to be visualized externally in the living embryo because of their deep positions. Much easier to see are the rapidly developing rudiments of the pectoral fins, Jaws and gills.

By day $31 / 2$ the hatched larva has completed most of its morphogenesis, and it continues to grow rapidly. Prominent changes during the next day are observed including the inflation of the swim bladder and the continued anterio-dorsal protrusion of the mouth. During the same time the gut tube drops more ventrally, where it can 
be seen more easily from the outside through the transparent skin of the body when the yolk extension nearly empties. Whereas during the hatching period the embryo is usually at rest, the early larva gradually begins to swim about actively, and moves its jaws, opercular flaps, pectoral fins ard eyes. These moves produce swift escape responses, seeking of prey and feeding.

\section{The effect of temperature on the embryonic development:}

The duration of each stage of embryonic development under various concentrations of $\mathrm{CuSO}_{4}$ is shown in Table (1). The rate of embryonic development of silver carp was shorter at the higher lemperature in both control and copper sulphate exposed groups. In the control embryos, at $20^{\circ} \mathrm{C}$, the entire development lasted about 92 hours, while at $26^{\circ} \mathrm{C}$ it only took about 75 hours. Temperature affected the time of both the beginning and the duration of the developmental stages. Considerable acceleration was observed at 23 hours post fertilization, segmentation stage, the difference was already about 4 hours and at the stage of eye pigmentation, the difference was about 13 hours. Hatching started almost 15 hours earlier at $26^{\circ} \mathrm{C}$ than at $20^{\circ} \mathrm{C}$.

\section{Toxicity test on the embryonic development:}

Severe defects during embryonic development arise in the experimental groups. The earlist detected harmful expression of $\mathrm{CuSO}_{4}$ was during cleavage as complete degeneration of the blastodisc (Plate I, 3) and complete rupture of the blastodisc (Plate I, 4) occurred. Many of the defects during embryonic development arise secondarily cascading from an early pattern disturbance that involves the movements of specific mesodermal cells during gastrulation as, somites did not form in the trunk. The tail bud did not develop to form the tail (Plate II, 7), death of the embryo just before hatching (Plate II, 8) and complete developed embryo could not hatch, due to ropable inhibition of chorionase activity ( Plate II, 9).

The exposure of the embryos to copper sulphate reduced the developing rate at both temperatures $(0.15 \mathrm{mg} / \mathrm{l}$ and $0.2 \mathrm{mg} / 1)$. Copper sulphate exposure resulted in the delay of hatching by 6 and 16 hours, respectively compared to the control. At the concentration of $0.3 \mathrm{mg} / \mathrm{l}$ copper sulnhate a considerable acceleration of development was 
Toxic and teratogenic effects of copper sulphate on the 235 developing embryos and larvae of silver carp

observed at $26^{\circ} \mathrm{C}$ as compared to that of $20^{\circ} \mathrm{C}$. At the latter concentration, the development stopped after the appearance of body segmentation after 36 hours of fertilization at $26^{\circ} \mathrm{C}$, and after the hatching stage, which starts at 105 hours after fertilization at $20^{\circ} \mathrm{C}$.

The exposure of the embryos to copper sulphate reduced the hatching rate at both temperatures. At $20^{\circ} \mathrm{C}, 0.15 \mathrm{mg} / \mathrm{l}$ and $0.2 \mathrm{mg} / \mathrm{l}$ copper sulphate decreased the percentage of hatched larvae by $9 \%$ and $30 \%$ respectively, while at $26^{\circ} \mathrm{C}$, the values were greatly elevated to $34 \%$ and $79 \%$ compared to the control values.

\section{Toxicity test on larvae:}

The quality of the larvae living in $\mathrm{CuSO}_{4}$-containing water was worse, compared to the controls, at both temperatures. At $20^{\circ} \mathrm{C}, 0.15$, 0.2 and $0.3 \mathrm{mg} / \mathrm{l}$ copper sulphate reduced the percentages of normal larvae to $10 \%, 31 \%$ and $88 \%$ respectively, while at $26^{\circ} \mathrm{C}$, these percentages reached $36 \%, 56 \%$ and $84 \%$. The percentage of the mortality increased in $\mathrm{CuSO}_{4}$-containing water comparing to the control one at both temperatures (Fig. 3). At $20^{\circ} \mathrm{C}, 0.15,0.2$ and 0.3 $\mathrm{mg} / \mathrm{l}$ copper sulphate increased the percentage of dead larvae to $6 \%$, $19 \%$ and $39 \%$ respectively, while at $26^{\circ} \mathrm{C}$, these percentages reached $13 \%, 27 \%$ and $49 \%$. At both temperatures, as the concentration of copper sulphate in the water increase, the percentage of deformed larvae increased compared to the control. The highest percentage of deformed larvae was found at the concentration of $0.3 \mathrm{mgl}$, as it constituted $25 \%$ of the treated embryos. At both temperatures, all normal young fish exposed to copper sulphate died gradually from the beginning of rearing. At $20^{\circ} \mathrm{C}, 0.2$ and $0.3 \mathrm{mg} / \mathrm{l}$ copper sulphate caused the death of fish after 8 - 9 days from the beginning of rearing (Fig. $4 \mathrm{~A}$ ). At $26^{\circ} \mathrm{C}, 0.2$ and $0.3 \mathrm{mgl}$, copper sulphate killed all normal fish faster than those in the $20^{\circ} \mathrm{C}$ water, after $4-5$ days from the beginning of rearing (Fig. $4 \mathrm{~B}$ ). The survival of the deformed larvae was considerably lower. At both temperatures, the strongly deformed fish in each group died in the 3rd day after rearing and the less deformed ones later on such as the group II, III at $26^{\circ} \mathrm{C}$, (Fig. $5 \mathrm{~B}$ ). At $26^{\circ} \mathrm{C} 0.3 \mathrm{mg} / 1$ copper sulphate caused growth inhibition. The delay of growth might have been related to underdeveloner? bladder which impaired fish activity and feeding . 


\section{The structure of normal sensory Organs}

\section{a) The free neuromasts:}

Generally, the system of free (surface) neuromasts occurs on the head (Plate III, 11) and trunk of teleost larvae and on silver carp larvae as well (Plate III, 14). The newly hatched larvae had free neuromasts with well developed cupulae anterior and beneath the eye ( Plate III, 11), The presence of the superficial position of these sensory organs (neuromasts), perform an effective function for receiving vibratory responses, which may be in the form of food substances or attacking predators. The newly hatched larvae of silver carp had superficial free neuromasts with well developed cupulae. Ai an age of about 4-5 days, about 10 prominent neuromasts with well developed cupulae are present on either flank (Plate III, 14). The free neuromast has two functions: mechanoreception and chemoreception. It becomes functional as a mechanoreceptor when it has well developed cupulae. The cupula is composed of cells arranged in two layers and at its top, a ciliated vesicle is present. The cilia are responsible for receiving vibratory responses. The cupulae seem to be very active in natural conditions.

\section{b) The eyes:}

The eyes of silver carp larvae become functional, when cones and rods of the retina are developed and the nerve fibers from the retinal ganglion cells connect with the optic tectum (Plate III, 12). At this time, visual sensitivity increase and the larvae start swimming and feeding.

\section{Neurotoxic effects on sensory organs :}

The neurotoxic effect of copper sulphate on silver carp, involves a retardation of the neurological development of the superficially located free neuromasts on the head and the defomation of cell projections (cilia of vesicle). These defects were observed in $0.3 \mathrm{mg} / 1$, at $26^{\circ} \mathrm{C}$ copper sulphate exposed larvae, (Plate III, 13). The ne.romasts which are segmentally arranged exhibit bi-directional prlarity (Platte III, 15). Copper sulphate exposed larvae exhibit lower differentiation of the eye at the higher concentration $(0.3 \mathrm{mg} / \mathrm{l}$, at $26^{\circ} \mathrm{C}$ ). Pale pigmentation, degeneration of the optic nerves which connect the eye to the tectum occurred. During this time, the larvae had poorly visual system and deformed mechanoreceptor cells, thereby, they can not detect the origin of mechanical stumuli (food 
Toxic and teratogenic effects of copper sulphate on the 237 developing embryos and larvae of silver carp

substances and predators) and hence their responsive behaviour for feeding was reduced and that in turn affects their growth.

\section{The structure of the normal vertebral column:}

The newly hatched larvae of silver carp had a notochord which appears as a cylindrical cartilaginous tube tapering posteriorly. The beginning of ossification around the notochord took place at the centrum of the occipital bone of 2 days old larvae. As the larvae grew, the ossification proceeds backwards. Ossifications proceeds both dorsally and ventrally from the centers past the neural or haemal arch bases towards the median line of the neural arch. As the cartilage became replaced by bony matrix, the ossified region became thinner (Platte IV, 16).

\section{Toxicity effect on the vertebral column:}

$0.3 \mathrm{mg} / 1$ copper sulphate exposed larvae, al $26^{\circ} \mathrm{C}$, had deflected spinal axies and when agitated, swimming was discoordinated and erratic. Fish with external lordosis also had deflected spinal axis, displaced vertebral centra, dislocated rib bones and dorsal and ventral vertebral spines, (Plate IV, 17, 18). Malformations of haemal and neural spines as well as ribs include mostly bone deformations as revealed by alizarine stained sections . However, the hypural bones of the tail remained largely alcian blue stained, suggesting that the calcification in fish was greatly delayed as compared to controls. Stained transverse sections (Plate V, 21, 22), revealed severe fractures of the vertebrae centers (arrows). During cartilage maturation, in the head around the otic region, (Plate $V$, 23) the cells became pyknotic, and the matrix between cells remain cartilaginous (alcian blue stained). This means delaying of ossification in copper exposed larvae. There were no noticeable changes in the vertebral and cartilage structure in fish at 0.15 and $0.2 \mathrm{mg} / \mathrm{l} \mathrm{CuSO} \mathrm{C}_{4}$

\section{DISCUSSION}

Copper sulphate was chosen in the present experiments. because it plays an important role as a microelement necessary for development and growth of the living organisms as it is bound in ceruloplasmin. However, it becomes a strong toxicant in excessive concentratis.m. Copper sulphate is used on a large scale as an algicide 
in lakes and reservoirs. It is considered to be very suitable for the control of algae because it forms heavy insoluble compounds with the proteins and of other constituents of algal cells which sink to bottom and are then removed from the main mass of water (Stominska, 1998 and Stominska and Jezierska, 2000)

\section{Embryogenesis}

Changes in structure-to-structure, organ-to-organ and/or organism-to-environment relationships are decisive for evaluating the developmental pattern of a species (Balon, 1979; 1990; 1999). In silver carp, the stages of embryonic development were distinguished according to Witeska et al. (1995). Ballard (1981) coined the term 'Pharyngula' to refer to the embryo that has developed to the phylotypic stage, when it possesses the classic vertebrate bauplan. According to von Baer's famous laws (discussed by Gould, 1977), this is the time of development when one can most readily compare the morphologies of embryos of diverse vertebrates. For silver carp, this time approximates the period at the 90 hours of embryonic development (Fig. 6 e). At this stage, the embryo is most evidently now a bilaterally organized creature, entering the pharyngula period (Fig. 6 e) with a well-developed notochord and a newly completed set of somites that extend to the end of a long post-anal tail.

\section{Effect of temperature on the carp embryonic development}

The results of the present study indicate that in control groups, the temperature affected the duration of embryonic development (Table 1). At $20^{\circ} \mathrm{C}$, the entire development lasted about 92 hours, while at $26^{\circ} \mathrm{C}$, it only took about 75 hours. Temperature affected the time of the beginning of the developmental stages and their duration, and the developmental rate considerably increased in about 15 hours post fertilization. These results confirm the data of other studies on other fish species (Tatarko, 1965; Leszczynski, 1967; Alderice and Forrester, 1968; Penz, 1974; Kokurewicz et al., 1978; Yulin, et al. 1990; Wang and Eckmann, 1993; Korwin-Kossakowski, 1994; Sikorska and Jerierska, 1997 and Lugowska and Jezierska, 2000) ithe present results also indicate that, the duration of hatching was longer at $26^{\circ} \mathrm{C}$ ( 30 hours) while at $20^{\circ} \mathrm{C}$ it only took 9 hours (Table 1 ). This delay of hatching might have been caused by the reduction of chorionase enzyme. Runn et al., 1977 and Hagenmaier, 1974, reported that the main limiting factors of fish development are the mechanisms involved in the hatchery process. These mechanisms are 
Toxic and teratogenic effects of copper sulphate on the 239 developing embryos and larvae of silver carp

connected with digesting of the egg envelope by chorionase enzyme. Dave and Xiu (1991) stated that delayed hatching of zebrafish exposed to copper might have resulted from osmoregulatory disturbances affecting the embryo muscles and inhibiting of chorionase.

The present data also show that, the conditions of embryonic development and the temperature at which the fish spent their days after hatching, strongly affected their viability. The effect of excessive temperature during development might have caused not only external malformation but also the disturbances which appeared during the larval stage (changes in swim bladder structure and locomotory mechanisms). The stage of filling of swim bladder was delayed mostly in the fish exposed to $3 \mathrm{mgl}$ copper sulphate Stouthart, et al. (1996) reported that the failure to fill the bladder might have resulted from under-development of the upper jaw and inability of air ingestion. They also suggested impaired gas bladder and oxygen resorption and secretion in the swim bladder of the common carp after copper toxicity.

\section{Toxicity effect of copper sulphate}

The data obtained in the present study indicate that, copper caused the extension of the entire development time. Prolonged embryonic development in copper exposure was also observed by Ellenberger et al. (1994). This was confirmed by the results of Mis and Bagaj (1997) concerning the inhibition of the hatching gland development by copper. The developmental stages between fertilization and the eyed stage appear to be the most sensitive to copper. Damaged blastodisc and blastula and highest mortality rates occurred during the first period of embryonic development of silver carp. These results was confirmed by Solbe and Shurben, 1989 on rainbow trout .

In the present study, copper sulphate considerably reduced larval hatchability, which was observed at $20^{\circ} \mathrm{C}$ and $26^{\circ} \mathrm{C}$ (Fig. 2). At $20^{\circ} \mathrm{C}, 0.15 \mathrm{mg} / 1$ and $0.2 \mathrm{mg} / 1$ copper sulphate decreased the percentage of the hatched larvae by $9 \%$ and $30 \%$, respectively, while at $26^{\circ} \mathrm{C}$ the values were greatly elevated to $34 \%$ and $79 \%$ comparing to control values. At the $0.3 \mathrm{mg} / \mathrm{l}$ concentration, the development stopped after the appearance of body segmentation. This confirms the 
data by other authors for various metals (Kapure and Yadav, 1982; Yulin et al. 1990; Jezierska et al., 1995; Jezierska and Stominska, 1997 ). The presented data indicate that copper sulphate caused increased frequency of body malformations and also increased the percentage of deformed larvae, resulting from the developmental disturbances, among which difficults during hatching may play an important role. Body malformations may also reduce the ability of fish to capture food, which results in death. Stominska (1998) reported that the incubation of the embryo in metal-containing water results not only in reduced survival rates, but also in worse quality of hatched larvae. Woodward et al. (1989) noticed that at pH 6.0 aluminium reduced by $67 \%$ the feeding rate in Oncorhynchus clarki swimm-up larvae. It is also probable that the larvae suffered from impaired ionic balance. Coyle et al. (1993) related increased mortality of bluegills after dietry selenium to the failure of exogenous feeding after yolk resorption. McKim and Benoit (1971) reported 24\% mortality of Salvelinus fontinalis after 3 months in $32.5 \mathrm{ug} \mathrm{dm}$ of $\mathrm{Cu}$, while all fish died after 4 months.

The present study shows that, growth inhibition might have been related to underdeveloped swim bladder which impaired fish activity and feeding. The stage of filling of the swim bladder was delayed most in the fish exposed to $0.3 \mathrm{mg} / 1$ copper sulphate. Similar results were obtained by Stominska and Jezierska (2000) and Hazel and Meith (1970) in common carp and Oncorchynchus tshawytscha, respictevely. The effect of copper on swim bladder filling in common carp was also observed by Stouthart et al. (1996). These authors supposed that the failure to fill the bladder might have resulted from underdevelopment of the upper jaw and inability of air ingestion. They also suggest impaired gas exchange and oxygen resorption and secretion in the swim bladder. Hwang et al. (1995) observed significant decrease of water, calcium and potassium content in Oreochromis mossambicus larvae exposed to cadmium.

\section{Sensory organs}

\section{The neuromasts}

The presence of the superficially positioned free neuromasts are characteristics of fish larval stages (Munz, 1979; Blaxter, et al. 1983; Metcalfe et al., 1985; Janssen et al., 1987; El-Fiky, 1993; ElFiky and Bahaa, 1994; Lashein, 1996; 1999). The present neurotoxic effect of copper sulphate on silver carp larvae involves a retaduni... 
of development of these superficialy located neuromasts, damaging of the cilia of their cupulae on the head and the appearance of radial polarity or bi-directional polarity of neuromasts on either flank. These neurotoxic effects inhibit their ability to react with environmental stimuli (food substances and predators). Similar results were obtained by Lashein (1999) who observed the neurotoxic effect of lead and cadmium on grass carp. He noted the dedifferentiation of the neuromast-cell hair tufts which resulted in poor feeding response. Poor feeding response and metal accumulation results in retarded growth as expressed in larval weight.

\section{The eyes}

Behaviour development in silver carp larvae occurs in association with the development of sensory organs (neuromasts and eyes). The eyes of the early larvae can be considered functional, when visual cells and pigments are present and nerve fibers from retinal ganglion cells connect with the optic tectum (El-Fiky, 1993 ; and ElFiky and Bahaa, 1994). In the present study, at $26^{\circ} \mathrm{C}, 0.3 \mathrm{mg} / \mathrm{l}$ copper sulphate exposed larvae exhibit a series of abnormal structures of the eyes, dedifferentiation of visual cells, pale pigmentation and weekness of optic nerves leading to sinking of eye ball.

\section{The vertebral column}

The notochord of the newly hatched larvae of silver carp appeared as a cylindrical cartilaginous tube tapering posteriorly. The ossification around the notochord took place at the centrum of the occipital bone. As the larvae grew the progressive ossificstion proceed backwards. Copper exposed larvae $\left(0.3 \mathrm{mg} / 1\right.$, at $\left.26^{\circ} \mathrm{C}\right)$ showed external lordosis and deflected spinal axis. The present study shows that copper sulphate caused inhibition of skeletal ossification which might have resulted from impaired ionic regulation. Reader $e t$ al. (1989) noted that copper reduced calcium uptake and bone calcification in Salmo trutta. Similar effect of lead was observed by Holocombe et al.(1976) in Salvelinus fontinalis. The authors suggest that lead inhibits enzymatic decomposition of tryptophan and may also cause inhibition of other enzymes. Lugowska and Jezierska (2000) observed visible body malformations of deformed larvae (vertebral curvature, edema, body shortening). These malformations cause impairment of swimming and feeding. The most deformed larvae usually die. 
In conclusion, the results of the present study show that copper sulphate in $0.15,0.2$ and $0.3 \mathrm{mg} / \mathrm{l}$ concentrations, at $20^{\circ} \mathrm{C}$ and $26^{\circ} \mathrm{C}$ temperatures, in the environment cause:

- Severe defects during embryonic development.

-Reduction of the development and growth rates.

- Developmental anomalies (inhibition of skeletal ossification, deformed neuromasts on the head and the flank, dedifferentiation of the eye and degeneration of the optic nerve leading to its disconnection to the tectum.

-Inhibition of the swim bladder development which impaired fish activity and feeding

\section{REFERENCES}

Alabaster, J. S. and Lloyd, R. (1980). "Water Quality Criteria for Freshwater Fish“. Butterworths London, Boston. 1-297.

Alderice, D.F. and Forrester, C.F. (1968).Some effects of salinity and temperature on early development and survival of the English sole (Parophrys vetulus). J. Fish Res. Bd, Can., 25(3): 495521.

Amend, D.A.; Yasutake, W.T. and Morgan, R. (1969). Some factors influencing suspectibility of rainbow trout to the acute toxicity of mercury phosphate formulation (timsan), Trans. Amer. Fish. Soc., 98: 419-425.

Ballard, W.W. (1981). Morphogenetic movements and fate maps of vertebrates. Am. Zool., 21:391-399.

Balon, E.K. (1979). The theory of saltation and its application in the ontogeny of fishes, steps and thresholds. Environ. Biol. Fish. , 4: $97-10$.

Balon, E.K. (1990). Epigenesis of an epigeneticist: the development of some alternative concepts on the early ontogeny and evolution of fishes. Guelph Ichthyological Review, 1: 1-48 
Toxic and teratogenic effects of copper sulphate on the 243 developing embryos and larvae of silver carp

Balon, E.K. (1999). Alternative ways how to become a definitive phenotype or a juvenile (and on some persisting linguistic offences). Environ. Biol. Fish ., 56: 17-38.

Bieniarz, K. ; Epler, P.; Sokotowska-Mikotjczyk, M. and Popek, W. (1997). Reproduction of fish in conditions disadvantageously altered with the salts of zine and copper. Arch. Ryb. Pol., 5: $21-30$.

Blaxter, J.H.S.; Best, A.C.G. and Gray, J.A.B. (1983). Structure and development of the free neuromasts and lateral line system of the herring. J. Mar. Biol. Assoc. U.K., 63: 247-260.

Bucke, D. (1972). Some histological techniques applicable to fish tissues, Pages 153-189 in L.E. Mawdesley-Thomas, ed. "Diseases of Fishes", Symp. Zool. Soc. Lond. No. 30. Academic Press, New York.

Coyle, J.J.; Buckler, D.R.; Ingersoll, G.; Fairchild, J.F. and May, T.W. (1993). Effect of dietary selenium on the reproductive success of bluegills (Lepomis macrochirus), Environ. Toxicol. Chem., 12: 551-565.

Dave, G. and Xiu, R. (1991). Toxicity of mercury, copper, nickel, lead and cobalt to embryo and larvae of Zebrafish, Brachydanio rerio, Arch. Environ. Contam. Toxicol., 21: 126134.

Dingerkus, G. and Uhler, L.D: (1977). Enzyme clearing of alcian blue stained whole small vertebrates for demonstration of cartilage. Stain Technol., 52(4): 229-232.

EL-Fiky N.K. (1993). Development of some sense organs of Cyprinus carpio and their relation to behaviour. J. Egypt. Ger. Soc. Zool., 10(3), Anatomy and Embryol., 273-292.

El-Fiky N.K. and Bahaa, K.M. (1994). A study of the development and free neuromasts appearance in the viviparous teleost, Gambusia affinis (Holbrook). Bull. Fac. Sci., Zagazig Univ., 16(2): 570-588. 
Ellenberger, S. A.; Baumann. P.C. and May, T.W. (1994). Evaluation of effects caused by high copper concentrations in Torch lake Michigan, on reproduction of yellow perch, J. Great lakes Res., ,20(3): 531-536.

Gould, S.J. (1977). "Ontogeny and Phylogeny" Cambridge: Harvard Univ. Press. 112pp.

Gupta, A. K. and Rajbanshi, V.K. (1988). Acute toxicity of cadmium to Channa punctatus (Bloch.), Acta Hydrochim. Hydrobiol., 5: 525-535.

Gutierrez, M.; Establier, R. and Arias, A. (1978). Uptake and Histopathological effects of cadmium and mercury to the Sapo (Halabatrachus didactylus). Invest. Pesq. 42(1): 141-154.

Hagenmaier, H.E. (1974). The hatching process in purified enzyme (Chorionase) from the hatchin fluid of the rainbow trout (Salmo gairdneri). Comp. Biochem. Physiol., 49(B): 315-324.

Hawang, P.P.; Lin, S.W. and Lin, H.S. (1995). Different sensitivities to cadmium in tilapia larvae (Oreochromis mossambicus; Teleostei), , Arch. Environ. Contam. Toxicol., 29: 1-7.

Hazel, Ch.R. and Meith, S.J. (1970). Bioassay of king salmon eggs and sac fry in copper solution, Calif. Fish Game., 56: 121-124.

Holcombe, G.W., Benoit, D.A.; Leonard, E.N. and McKim, J.M. (1976). Long-term effects to copper and lead. Exposure on three generations of brook trout (Salvelinus fontinalis), J. Fish. Res. Bd Can., 33: 1731-1741.

Janssen, J.; Coombs, S.; Hoekstra, D. and Platt, C. (1987). Postembryonic growth and anatomy of the mottled sculpin, Cottus bairdi (Scorpaeniformes: Cottidae). Brain Behav. Evol., 30(3): 210-229.

Jezierska, B. (1998). Malformations of cyprinid embryos and larvae after exposure to copper and lead. Second international conference: Trace elements-effects on organisms and environment. Book of abstracts, Cieszyn 23-26 June 1998, 64. 
Toxic and teratogenic effects of copper sulphate on the 245 developing embryos and larvae of silver carp

Jezierska, B. and Stominska, I. (1997). The effect of copper on common carp (Cyprinus carpio L.) during embryonic and postembryonic development. Pol. Arch. Hydrobiol., 44: 261272.

Jezierska, B.; Stominska, I. and Witeska, M. (1995). Effect of copper and lead on the quality of newly hatched carp larvae. Kom. Ryb., 4: 19-21.

Kapur, K. and Yadav, N. A. (1982). The effects of certain heavy metal salts on the development of eggs of common carp (Cyprinus carpio L.) Var. Communis, Acta Hydrochim. Hydrobiol., 10: 517-522.

Kawase, H. (1996). Radial polarity of the first neuromast in embryonic American shad, Alosa sapidissima (Teleostei: Clupeomorpha). Copeia, 1:226-228.

Kokurewicz, B.; Kowalewski, M. and Witkowski, A. (1978). Effect of temperature on embryonic development of European tench, Gosp. Ryb,. 2: 6-18.

Korwin-Kassakowski, M. (1994). Effect of temperature on grass carp incubation, Arch .Ryb., Pol., 1: 14-15.

Lashein, F.M. (1996). Effect of the heavy metals on the embryogenesis and larval development of the teleost fish. Ctenopharyngodon idella Ph.D. Thesis, Fac. Sci., Sohage. South Valley University.

Lashein, F.M. (1999). Effect of cadmium and lead on the skin neuromast cells differentiation and larval growth of the grass carp, Ctenopharyngodon idella (CUV. \& VAI.,, 1844), Egypt. J. Zool., 33: 307-320.

Leszcynski, T. (1967). Thermal conditions in silver carp eggs incubation, Gosp. Ryb., 10:6-18.

Lloyd, R. (1960). The toxicity of zinc sulphate to rainbow trout, Ann. Appl. Biol., 48: 84-94. 
Lugowska, K. and Jezierska, B. (2000). Effect of copper and lead on common carp embryos and larvae at two temperatures. Folia Univ. Agric. Stetin. 205 Piscaria, 26: 29-38.

Macleod, J.C. and Pessah, E. (1973). Temperature effects on mercury accumulation, toxicity and metabolic rate in rainbow trout (Salmo gaidneri), J. Fish. Res. Bd. Can., 30: 485-492.

McKim , J.M. and Benoit, D.A. (1971). Effects of long-term exposures to copper on survival, growth and reproduction of brook trout (Salvelinus fontinalis), J. Fish. Res. Board Can., 28: 608-616.

Metcalfe, W.K.; Kimmel, C.B. and Schabtach, E. (1985).Anatomy of the posterior lateral line system in the young larvae of the zebrafish. J. Comp. Neurol., 233: 377-389.

Mis, I. and Bagaj, J. (1997). Hatching gland of carp (Cyprinus carpio l.) embryos from the eggs incubated at various concentrations of zinc or copper, Pol. Arch, Hydrobiol., 44: 153-155.

Mis, J.; Bieniarz, K. (1997). Hatching glands of carp (Cyprinus carpio L.) embryo from the eggs incubated at various concentrations of zinc or copper, Pol. Arch. Hydrobiol., 44: 153-155.

Mis, J.; Bieniarz. K.; Epler, P. Sokotowska-Mikotajczyk, M. and Chyb. J. (1995). Incubation of fertilized common carp (Cyprinus carpio L.) eggs in different concentration of copper, Pol. Arch. Hydrobiol., $42: 267-276$.

Munz, H. (1979). Morphology and innervation of the lateral line system in Sarotherodon niloticus (L). Zoomorphol., 93: 73-86.

Park, E.H. and Kim, S.D. (1984). A procedure for staining cartilage and bone of whole vertebrate larvae while rendering all other tissues transparent. Stain Technol., 59(5).

Penz, M. (1967). Influence of water temperature on incubation and hatching in Chondrostoma nasus (L. 1758), Zool. Listy ,23: 53-59. 
Reader, J.P. Everall, N.C. Sayer, M.D.J. and Morris, R. (1989). The effects of eight trace metals in acid soft water on survival, mineral uptake and skeletal calcium deposition in yolk-sac fry of brown trout, Salmo trutta L. J. Fish. Biol., 35: 187-198.

Richards, V.L.; Beitinger, TL (1995). Reciprocal influences of temperature and copper on survival of fathead minnows, Pimephales promelas, Bull. Environ. Contam. Toxicol.. 55: 230-236.

Roberts, R.J. and Shephered, C.J. (1974). Handbook of trout ans salmon diseases. Fishing News (Books), West Byflect, 168pp.

Runn, P.; Johansson, N.; and Milbrink, G. (1977). Some effects of low $\mathrm{pH}$ on the hatchabilty of eggs of Perch, Perca fluviatilis $L$. Zoom, 5: 115-125.

Sarnowski, P, P. and Jezierska, B. (1999). The effect of lead exposure on grass carp, spermatozoa and developing embryos. In Heavy metals in the Environment: An integrated approach",. D.A. Lovejoyed, Institute of Geology, Vilnius, Lithuanea, 304-308.

Sarnowska, K.; Sarnowski, P. and Stominska, I. (1997). Effect of lead and copper on grass carp (Ctenopharyngodon idella) embryonic development. Materialy 17. Zjazdu hydrobiologow polskich: 173-174.

Schnick, R.A. (1974). Formalin as a therapeutant in fish culture. U.S. Wildl. Serv., Lit. Rev. 70-90 NTIS (Nat. Tece. Inform. Serv.) No Pb-235. 448/AS 145pp.

Sikorska, R. and Jezierska, B. (1997). Effect of temperature on embryonic development of grass carp. Materiaty 17. Zjazdu hydrobiologow Polskich: 174-175.

Solbe, J.F. and Shurben, D.G. (1989). Toxicity of ammonia to early life stages of rainbow trout (Salmo gairdneri), Wat. Res., 23: 127-129. 
Stominska, I. (1998). Susceptibility of juvenile forms of common carp (Cyprinus carpio) to toxic activity of lead and copper. Dissertation, AP Siedlce.

Stominska, I. and Jezierska, B. (2000). The effect of heavy metals on postembryonic development of common carp, Cyprinus carpio L. Arch. Ryb., Pol., 8: 119-128.

Stominska, I.; Jezierska, and B. Witeska, M. (1999). The effect of lead on common carp embryos. Heavy metals in the environment: An integrated approach,". D.A. Lovejoyed, Institute of Geology. Vilnius, Lithuania ,1999: 299-303.

Stouthart, A.J. Haans, J.L.M.; Lock, A.C. and Wandelaar Bonga S.E. (1996). Effects of water $\mathrm{pH}$ on copper toxicity to early life stages of common carp (Cyprinus carpio), Environ. Toxicol., Chem., 15: 376-383.

Tatarko, K.I. (1965). Effect of temperature on common carp embryonic development, Gidrobiol. Z., 1: 62-66.

Vidal, I.L (1978). Copper in the livers of trout caught below a sewage discharge , N.Z.J. Mar. Freshwa. Res. ,12(2): 217-220.

Wang, N. and Eckmann. R. (1993). Effects of temperature and food density on egg development, larval survival and growth perch (Perca fluviatilis L.), Aquacult., 122: 323-333.

Wiener, J.G. and Giespy, Jr.J.P. (1978). Concentration of cadmium, copper, manganese, lead and zinc on fishes in a highly organic salt water pond. J. Fish Res. Bd. Can., 36(3): 270-279.

Williams, H. A. and Wooten, R. (1981). Some effects of the therapeutic levels of formalin and copper sulphate on blood parameters in rainbow trout. Aquacult., 24:341-353.

Witeska , M.: Jezierska, B.; Chaber, J. (1995). The influence of cadmium on common carp embryos and larvae, Aquacult., 129: 129-132. 
Toxic and teratogenic effects of copper sulphate on the 249 developing embryos and larvae of silver carp

Wong. M.H., Luk, K.E. and Choi, K.Y. (1977). The effects of zinc and copper salts on Cyprinus carpio and Ctenopharyngodon idellus, Acta Anat., 99(4): 450-454.

Woodward, D.F.; Farag, A.M.; Mueller, M.E.; Little, E.E.; Vertucci, F.A. (1989). Sensitivity of endemic snake river cutthroat trout to acidity and elevated aluminium. Trans. Am. Fish. Soc. , 11.8: 630-643.

Wiener, J.G. and Giespy, Jr.J.P. (1978). Concentration of cadmium, copper, manganese, lead and zinc on fishes in a highly organic salt water pond. J. Fish Res., Bd. Can. 36(3): 270-279

Williams, H. A. and Wooten, R. (1981). Some effects of the therapeutic levels of formalin and copper sulphate on blood parameters in rainbow trout. Aquaculture 24:341-353.

Witeska , M.; Jezierska, B. and Chaber, J. (1995). The influence of cadmium on common carp embryos and larvae. Aquacult... 129: 129-132.

Yediler, A.; Jacobs, J. (!995). Synergistic effects of temperatures, oxygen and water flow on the accumulation and tissue distribution of mercury in carp (Cyprinus carpio), Chemosphere 31 (11/12): 4437-4453.

Yulin, W., Hongru, Z., Lanying, H: (1990). Effects of heavy metals on embryos and larvae of flate fish, Paralichthysolivaceus. Oceanol. Limnol. Sin., 4: 450-469. 


\section{Legend of Figures:}

Watc I : 1,2,3,and 4, face views of early embryonic period, (1), the normal zygot within chorion, a few minutes after fertilization, the animal pole face the observer. (2), damaged blastodisc (arrow) stoped to divid after $0.2 \mathrm{mg} / \mathrm{l}$ copper sulphate exposure, at $20^{\circ} \mathrm{C}$. (3), damaged blastodisc (arrow) degenerated as a result of $0.2 \mathrm{mg} / 1$ copper-exposure, at $26^{\circ} \mathrm{C}$. (4), a complete degeneration of blastodisc (arrow) as a result of $0.3 \mathrm{mg} / \mathrm{l}$ copper exposure, at $26^{\circ} \mathrm{C}$. (5), a normal embryo of 23 hours during segmentation period (chorion removed and shown at higher magnification), notice unpigmented eye. (6), Dead embryo of 35 hours (chorion uplifted) as a result of $0.3 \mathrm{mg} / 1$ copper sulphate - exposure $(0.3 \mathrm{mg} / 1)$, at $20^{\circ} \mathrm{C}$. Scale bar: 250 um.

Plate II : (7), Malformed embryo of 80 hours, (shown within the chorion) lacking extended tail (arrow) as a result of $0.2 \mathrm{mg} / \mathrm{l}$ copper exposure, at $200 \mathrm{C}$. (8), dead embryo of 88 hours (shown within the chorion), the notochord differentiated, somites appear sequentially along the axis, the tail extended, and the central nervous system and sensory organs became prominent, but the embryo did not hatch. (may be as a result of the inhibition of chorionase activity) as a result of $0.2 \mathrm{mg} / \mathrm{l}$ copper sulphate exposure, at $260 \mathrm{C}$. (9), a normal moving embryo of 90 hours (shown within the chorion), just before hatching. (10), normal hatched larva (91 hours after fertilization) is supported by the notochord, which extends most of the length of its length. In the trunk and tail, the notochord is surrounded by segmented series of somites that will give rise to trunk muscles and vertebrae. The brain is prominent and well developed and sensory organs such as the eye $(\mathrm{E})$ ear, otic vesicle $(\mathrm{O})$, and nose $(\mathrm{N})$ olfactory epithelium are present. The primordial of the pharyngeal segments, or arches are just beginning to form. Scale bare $=250 \mathrm{um}$. 
1 oxic and teratogenic effects of copper sulphate on the 251 developing embryos and larvae of silver carp

Plate (III): Scanning electron micrographs showing. (11), normal placodes of free neuromasts around the head near nostrils $(N)$ and around the eye (E). The neuromasts composed of a ciliated vesicle and rudimentary cupula. (12) a normal larva ( 9 days old) which have well pigmented eye and formed cones. The optic nerve fibers (arrows) can be seen leaving the eye and decussating to enter the tectum. (13) a deformed larvae of 9 days old which was exposed to $(0.3 \mathrm{mg} / \mathrm{l})$ copper solution, at $260 \mathrm{C}$, in which we can notice the damaged cilia of the sensory cells of neuromasts (arrows) and degeneration of optic nerves that lead to sinking of the eye ball (arrows). (14) part of a normal larva at an age of 8 days that have neuromasts with well developed cupulae which are present on either flank. In some places the neuromasts are paired on both sides of the body and on other places they are less regular. (15) deformed cupulae can be seen in a larvae of 8 days old exposed to $0.2 \mathrm{mg} / \mathrm{l}$ copper solution at $20 \mathrm{oC}$. Notice the appearance of radial polarity or bi-directional polarity of the cupulae of neuromasts (arrows). Scale bar $=100 \mathrm{um}$.

Plate (IV): Photomicrographs of parts of cleared and stained larvae of silver carp, showing, (16) part of the vertebral column of a normal larva of 10 days old. (17) part of the skeleton of a larva with external lordosis after $0.3 \mathrm{mg} / \mathrm{l}$ copper sulphate exposure for 10 days, at $260 \mathrm{C}$. Notice the deflected spinal axis , displaced vertebral column, dislocation of rib bones and the malformation of the haemal and neural spines. (18), the pelvic region showing a slight curvature of the vertebral column of a larva treated in $0.3 \mathrm{mg} / \mathrm{l} \mathrm{Cuso} 4$ for 10 days, at 26oC. X 40 magnification.

Plate (V): Photomicrographs of part of the transverse sections through the trunk region of the developing larvae showing, (19) 10 days larva showing the normal structure of the centrum and neural spine. (20) 8 days larva reared in $0.2 \mathrm{mg} / \mathrm{l} \mathrm{Cuso} 4$ at $20 \mathrm{oC}$ showing a normal structure of the centrum, but the cartilage cells of the neural spine became pyknotic. (21 and22) showing swelling of both the centrum and the neural spine after $0.3 \mathrm{mg} / \mathrm{l}$ copper sulphate -exposure for 10 days at $26 \mathrm{oC}$. 
Not (arrows) destruction in vertebral structures and cartilage cells of neural spines that became pyknotic. (23) 9 days larva reared in $0.2 \mathrm{mg} / \mathrm{l}$ Cuso 4 at $260 \mathrm{C}$ showing the cartilage cells of the head that became pyknotic. X 330 . 

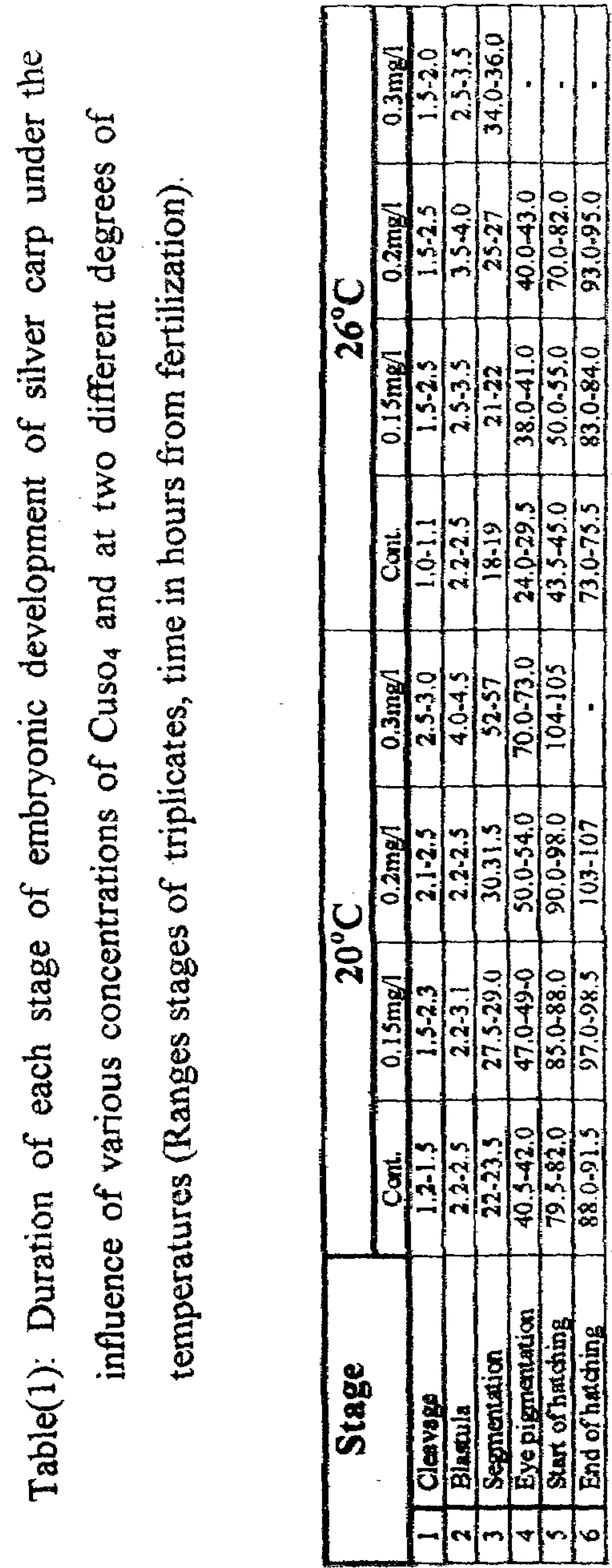


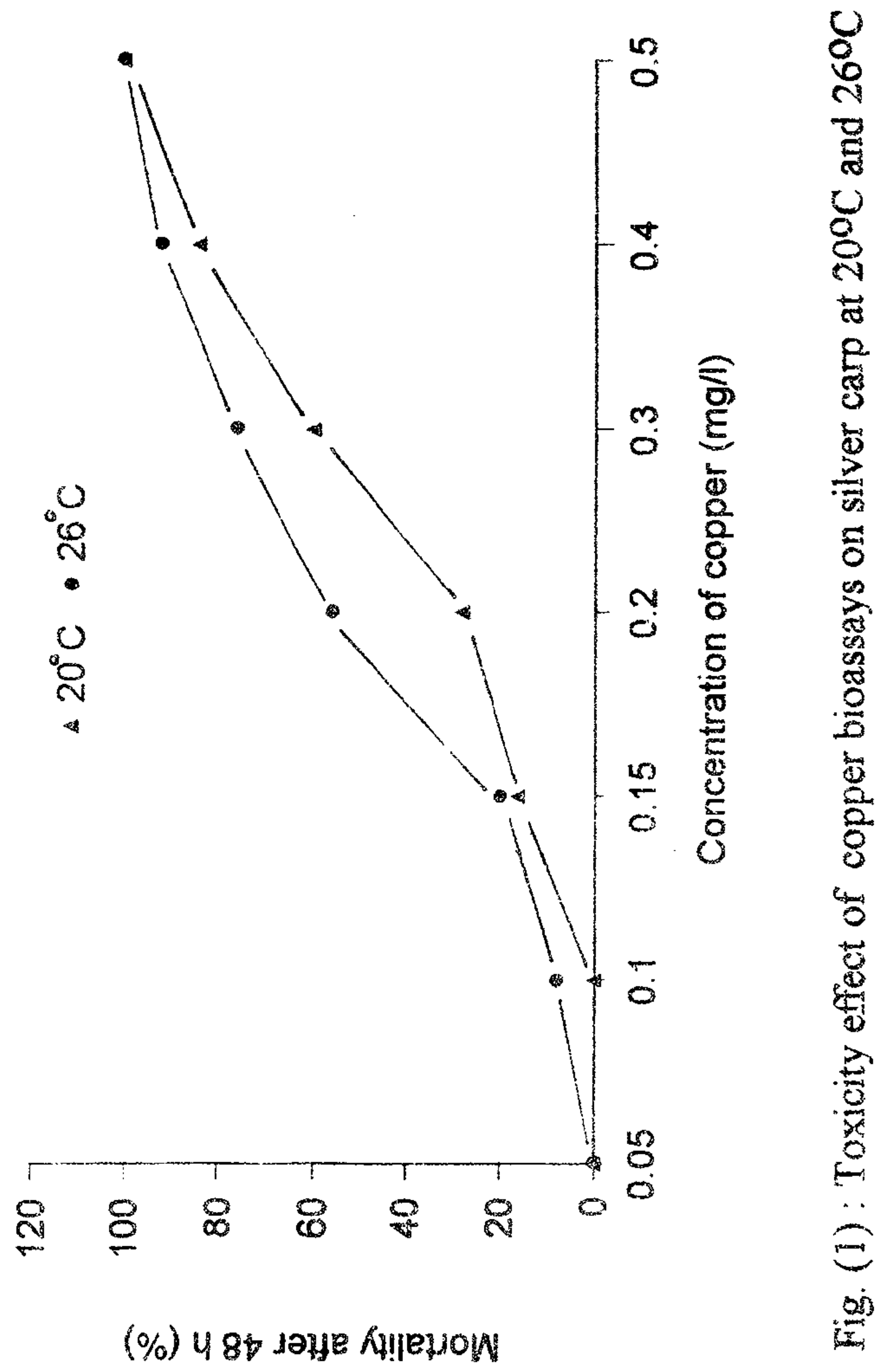




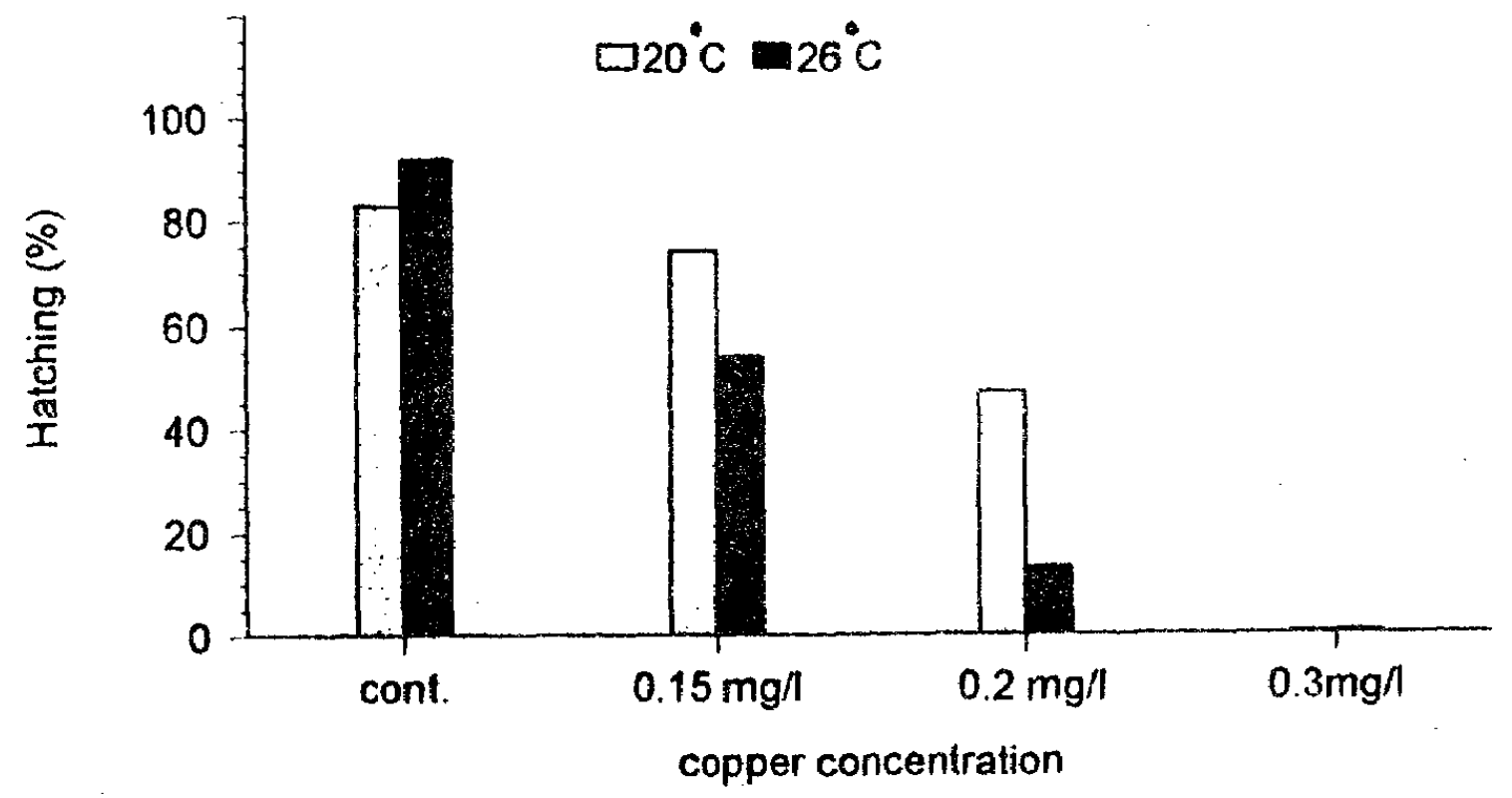

Fig. (2) : The effect of copper solutions on hatching. (average from 3 replicates).

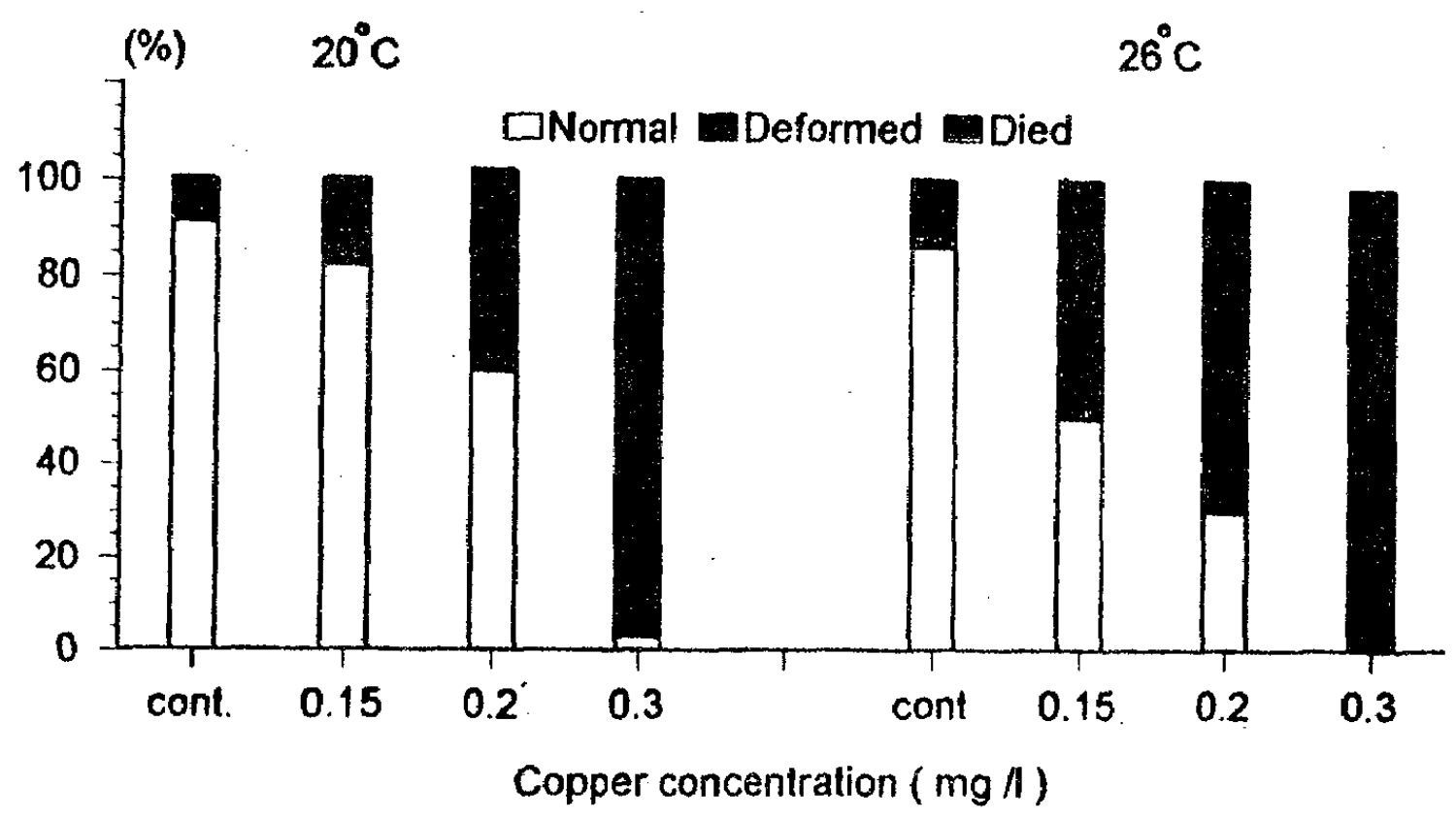

Fig. (3) : Share of normal, deformed and dead hatch after copper sulphate exposure, at $20^{\circ} \mathrm{C}$ and $26^{\circ} \mathrm{C}$. (average from 3 replicates). 

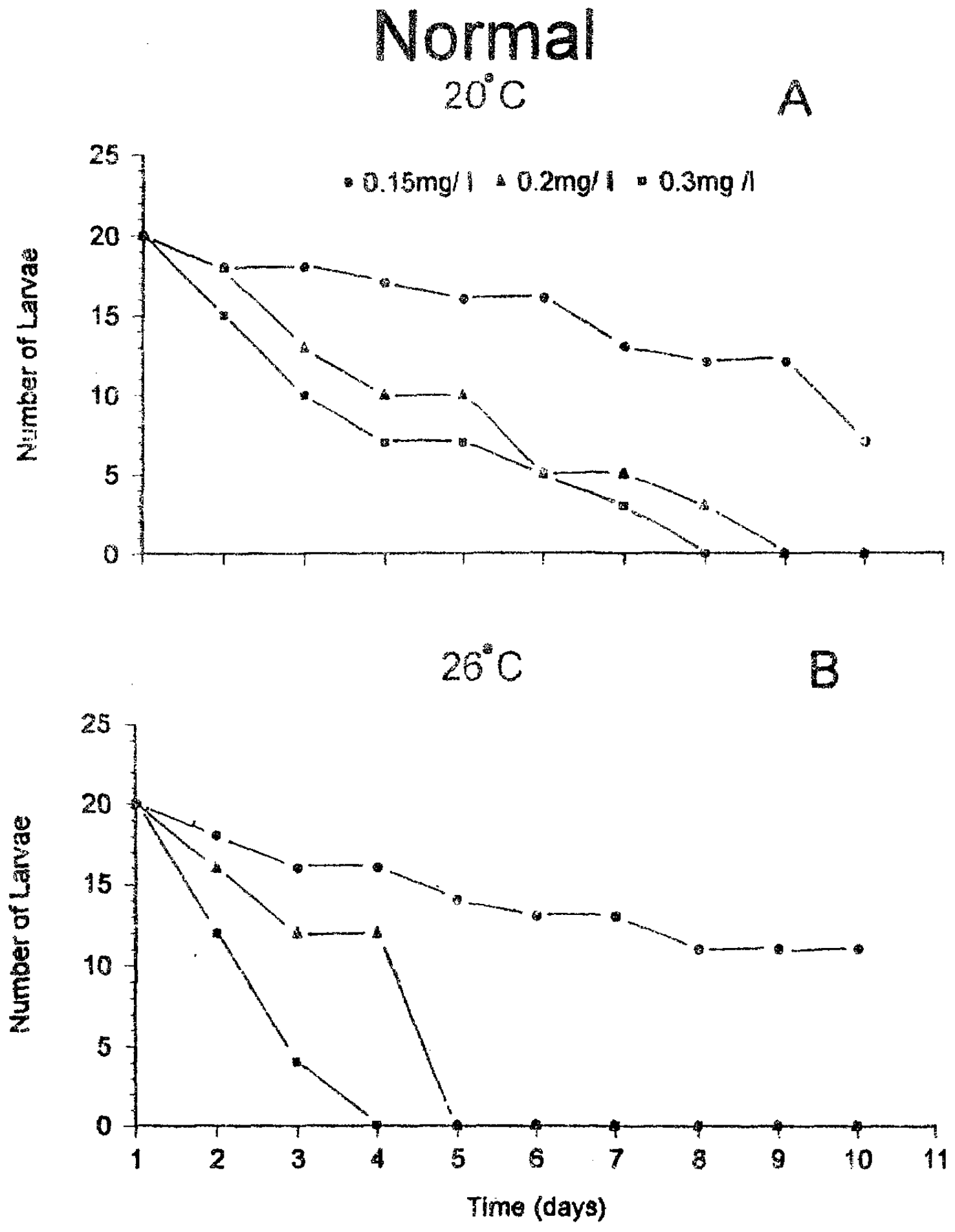

Fig. (4) : Survival of remaining normal larvae exposed to copper solution $(0.2 \mathrm{mg} / \mathrm{l})$, at $20^{\circ} \mathrm{C}(\mathrm{A})$ and $26^{\circ} \mathrm{C}(\mathrm{B})$ 

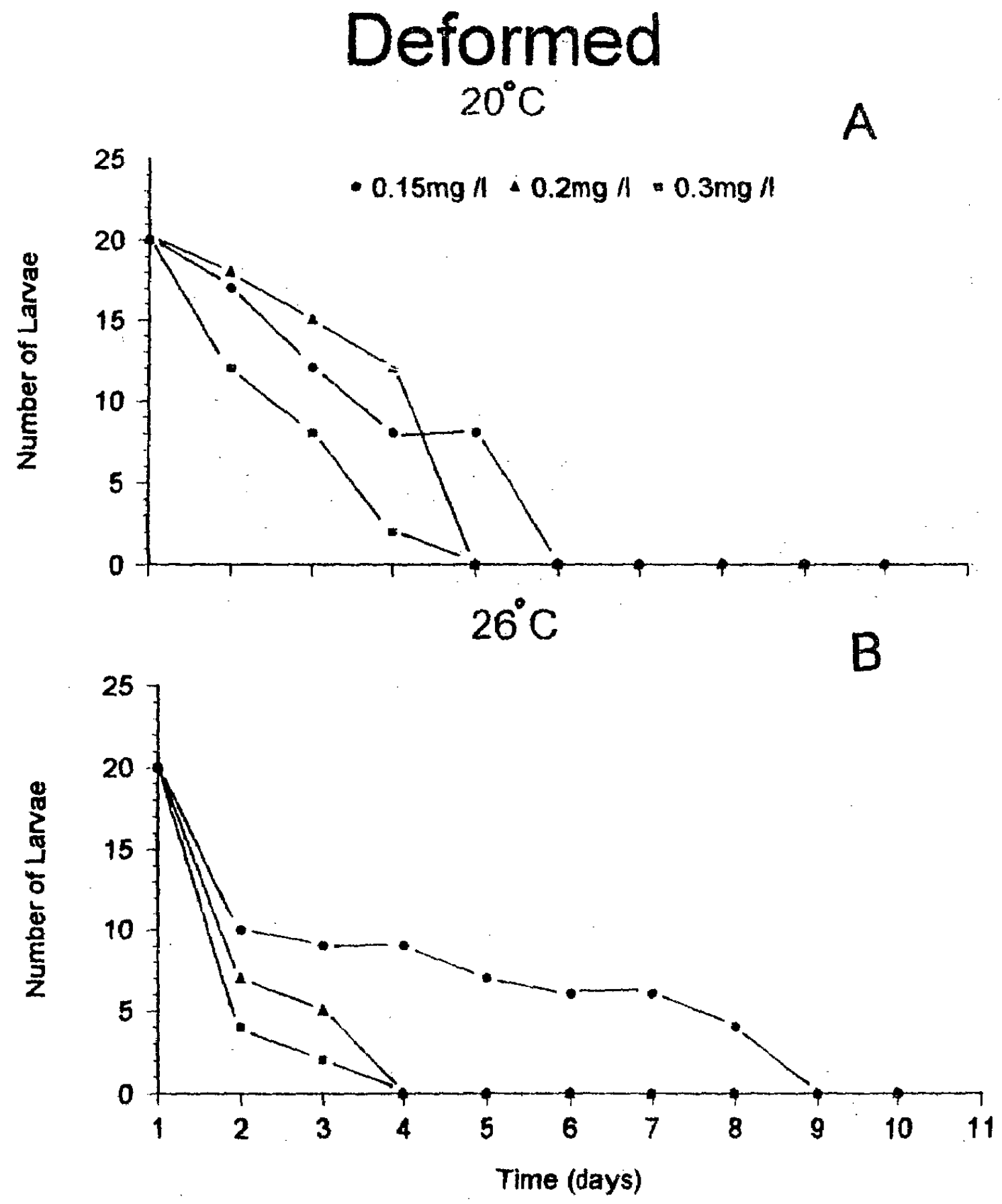

Fig. (5) : Survival of deformed larvae exposed to copper solution $(0.2 \mathrm{mg} / 1)$ at $20^{\circ} \mathrm{C}$ (A) and $26^{\circ} \mathrm{C} \mathrm{B}$ ).. 
Fig. (6) : Schematic diagrams illustrating various stages of the embryonic developrnent of silver carp. (a), 4-blastomeres stage. The blastodisc divides to form 4-blastomers, while the yolk region does not divid. (b), the blastula, a series of rapid divisions produce an undifferentiated ball of cells blastula perched on top of the non-dividing yolk . (c) Segmentation stage showing. a variety of morphogenetic processes which occur during the segmentation period. The notochord differentiates, somites appear sequentially along the axis, the tail extends greatly, and the central nervous system and sensory organs become prominent. (d), The tail bud stage. (e), 90 hours embryos showing, all the characters of vertebrates phylotypic stage. (f), the newly hatched larva. Abbreviations, (AN), anus; (B), blastodisc; (CH), notochord; (BN), brain; (E), eye; $(\mathrm{O})$, otic vesicle; $(\mathrm{S})$, somite; $(\mathrm{TB})$ tail bud; $(\mathrm{H})$, head region; (YS), yolk sac.

(a)

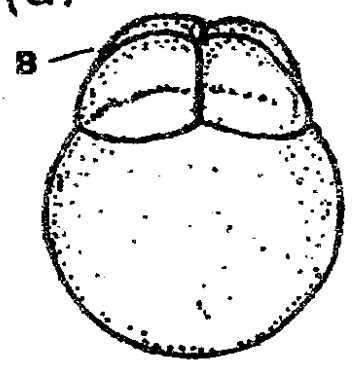

1.2-1.5 hours (cleavage stage)

(c)

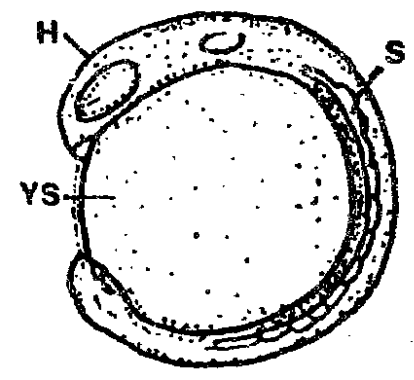

40-42 hours (tail bud stage)

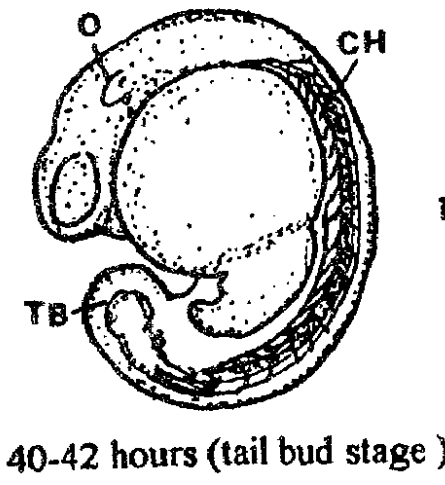

$22-23$ hours (segmentation stage) (f)

(b)

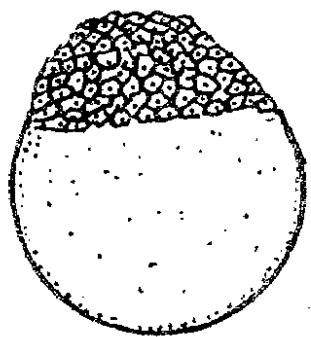

2.2-2.5 hours (blastula stage)

(d)

(e)

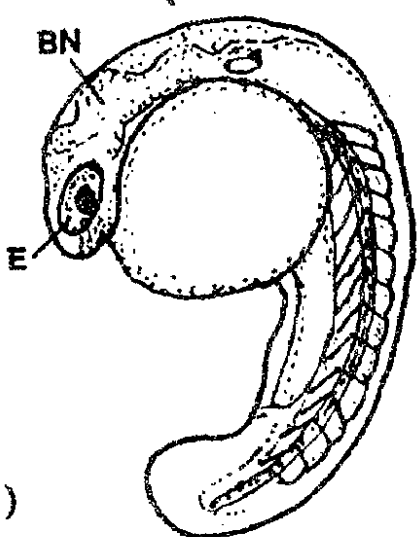

79-82 hours (Pharyngula stage)

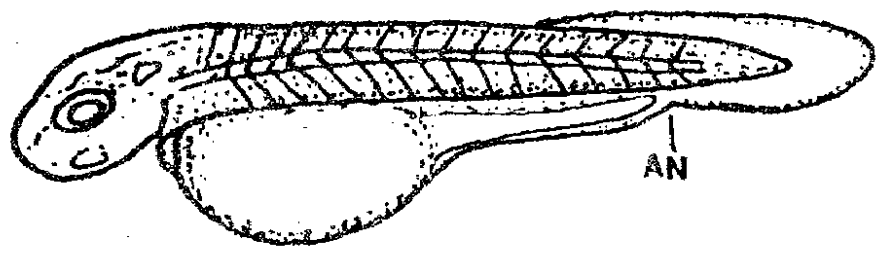

88-91 hours (end of hatching stage) 
Plate 1

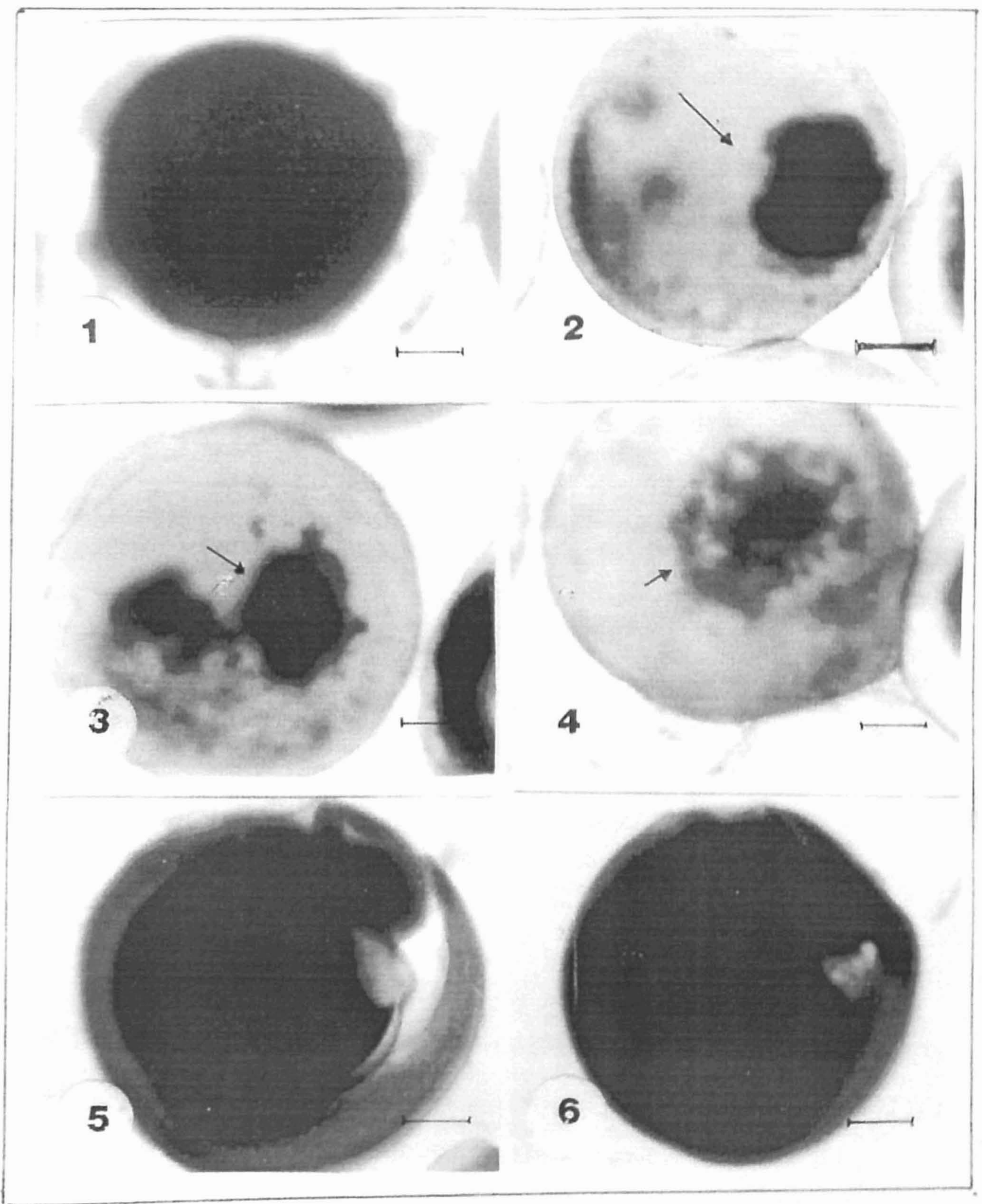


Plate.II

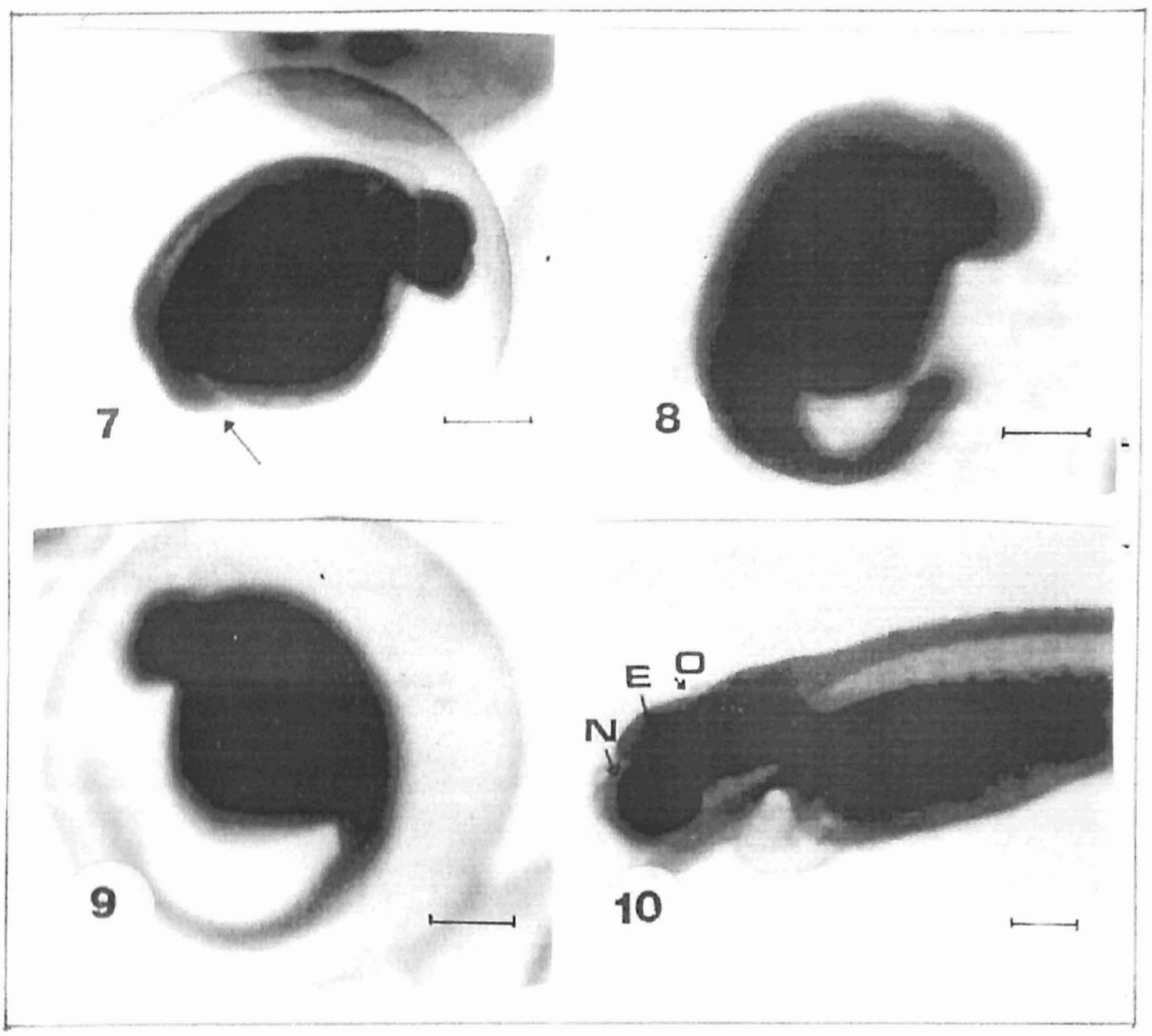




\section{Plate.III}
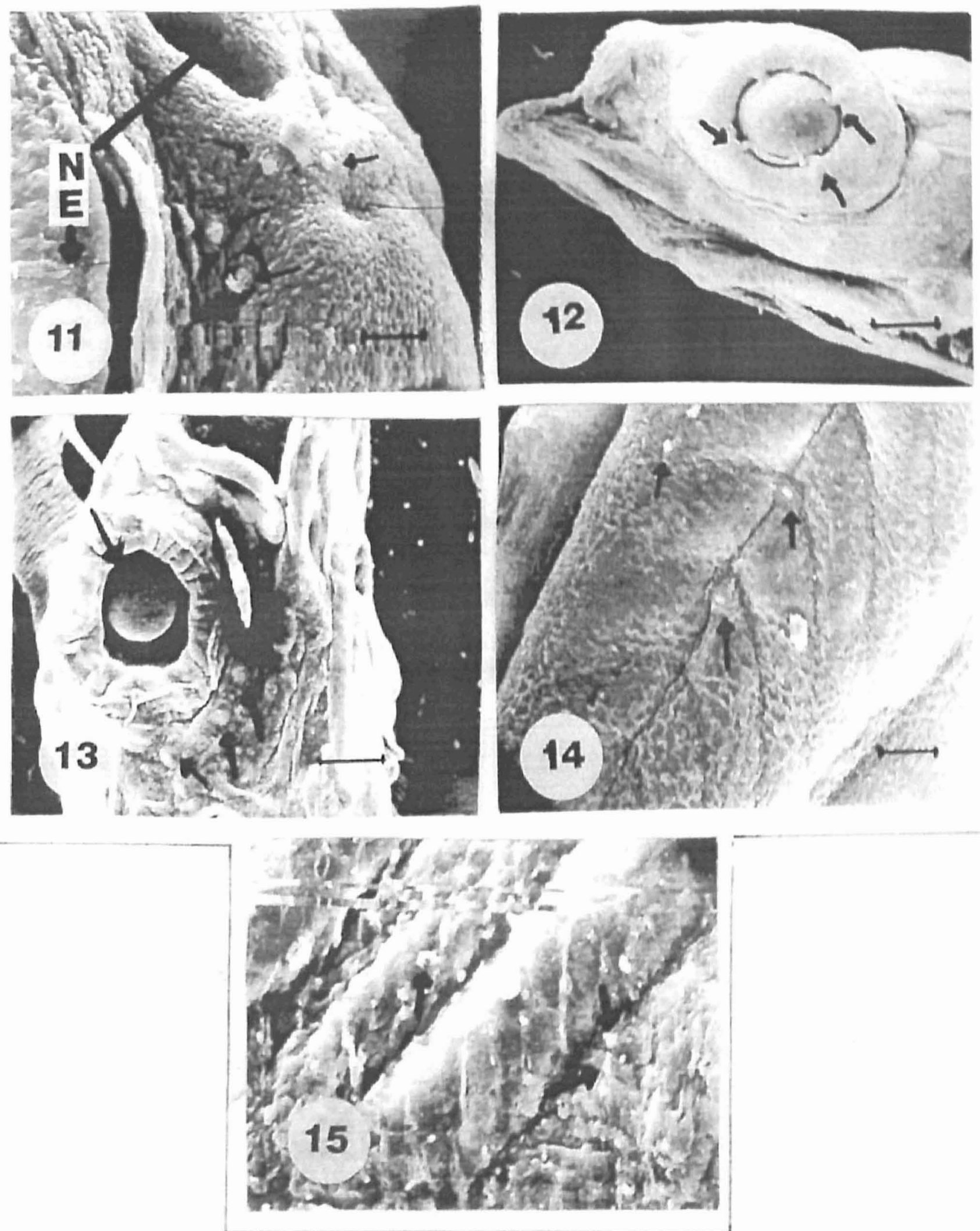
Plate. IV

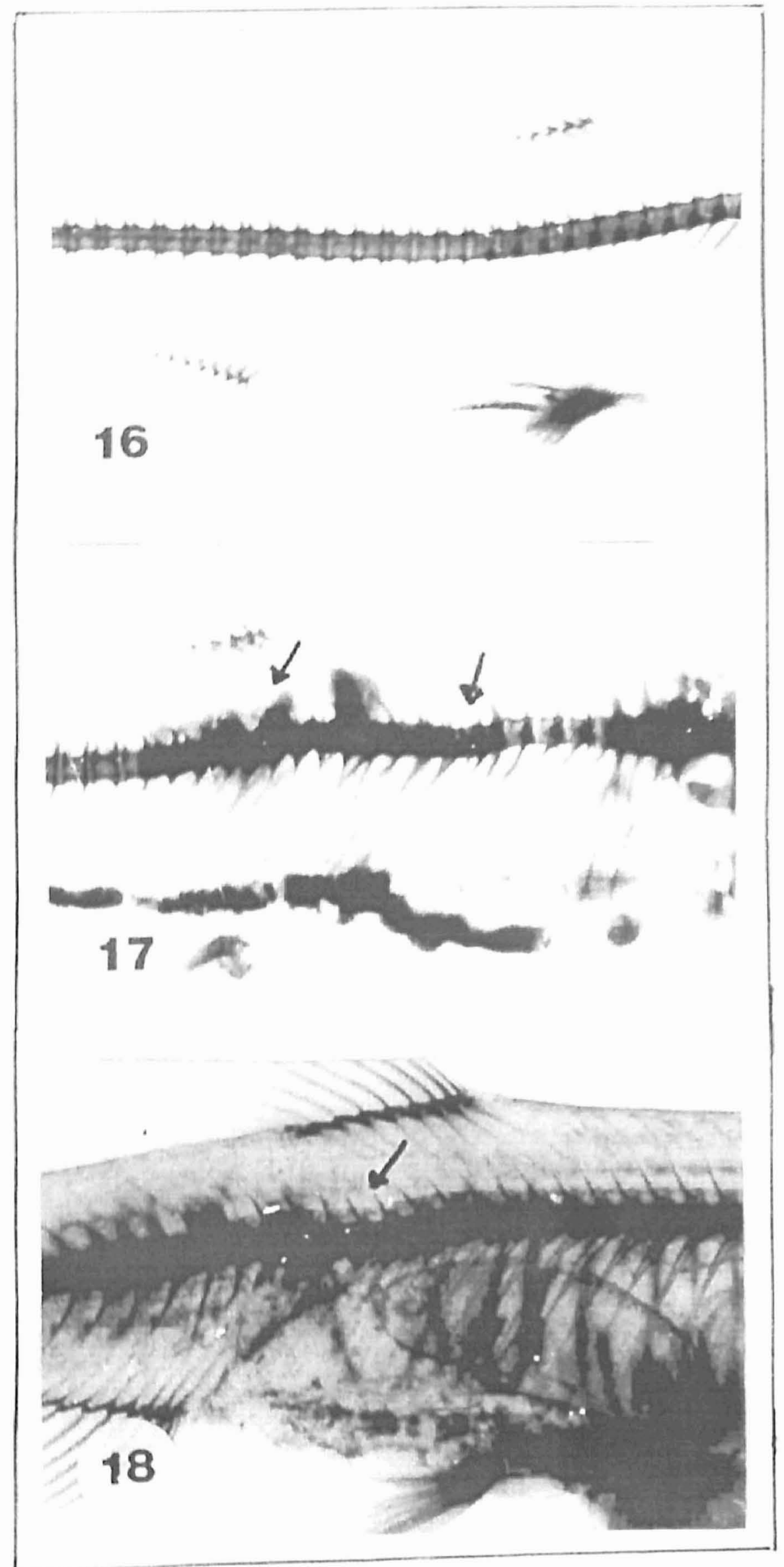




\section{Plate V}

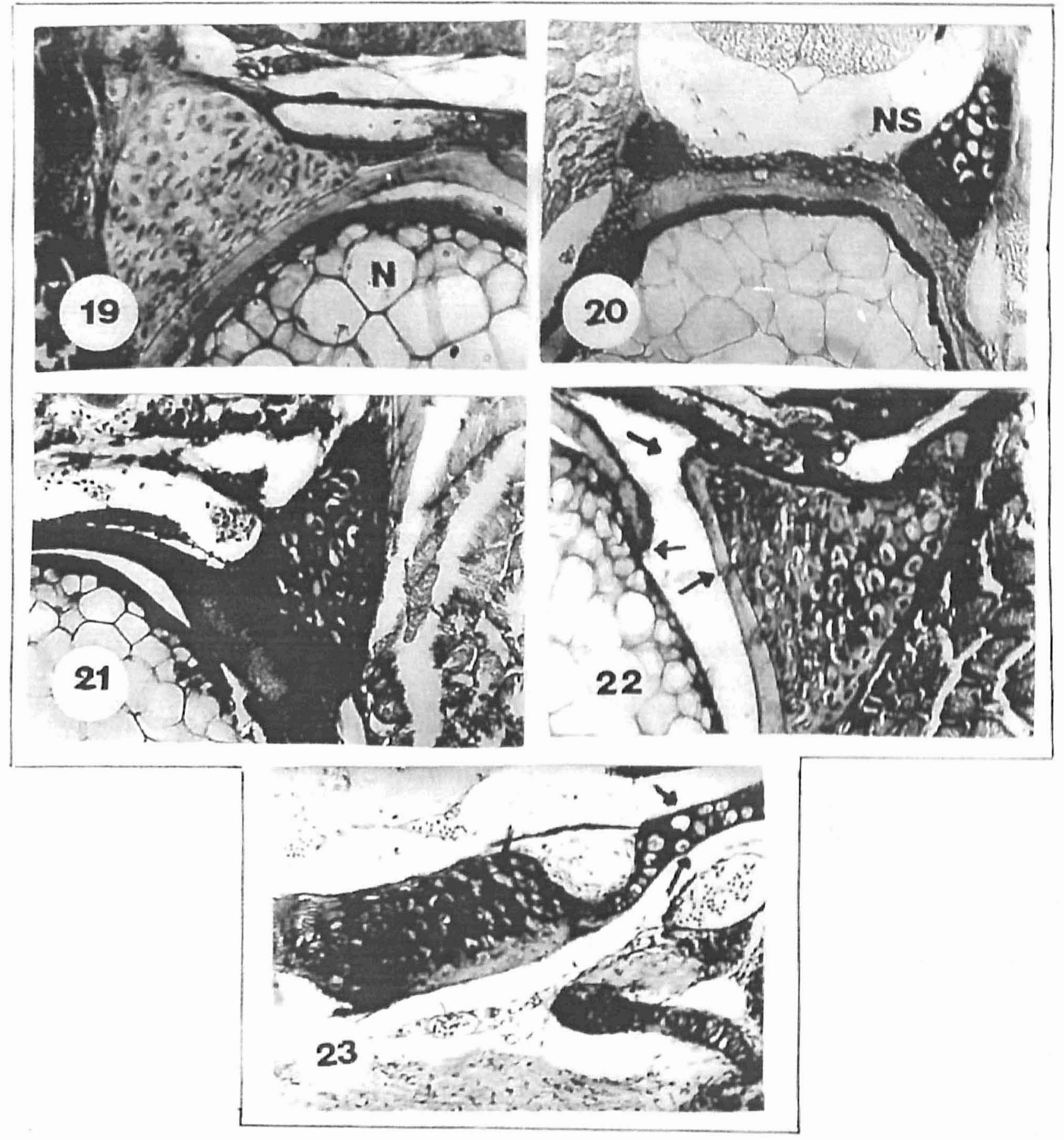

